\title{
X-Ray Diffraction in Cultural Heritage and Archaeology Studies
}

\author{
Enrico Franceschi \\ Department of Chemistry and Industrial Chemistry, University of Genoa, Via Dodecaneso 31, 16146 Genova, Italy \\ Email: franceschi@unige.it
}

Received 15 April 2014; revised 20 May 2014; accepted 30 May 2014

Copyright (C) 2014 by author and OALib.

This work is licensed under the Creative Commons Attribution International License (CC BY). http://creativecommons.org/licenses/by/4.0/

(c) (i) Open Access

\begin{abstract}
$\mathrm{X}$-ray powder diffraction methods have been more and more extensively used, in the last twenty years, in the characterization of different crystalline and non-crystalline materials of archaeological, historical, artistic interest. The present paper aims to discuss the use of these methods in studying different aspects related to the Cultural Heritage conservation. This purpose has been achieved by examining the results obtained during the studies carried out by the author and his collaborators on a number of objects formed by different materials, such as cellulose, paper, wood, papyrus, archaeological glasses, mosaics (non crystalline or only partially crystalline materials), ceramic, metals, their corrosion products, slags, stones, mortars, pigments (partially or almost completely crystalline materials).
\end{abstract}

\section{Keywords}

\section{X-Ray Diffraction, Cultural Heritage, Archaeology, Archaeometry}

\section{Introduction}

With the ever-expanding world of studies on artistic, historical and archaeological materials [1], it is a very hard task to think of writing a comprehensive paper on this subject.

The aim of this work is to present the contribution that X-ray diffraction may offer in the field of Cultural Heritage and archaeological studies, starting from the personal experience of the author and his collaborators, mainly concerning cellulose-based materials, archaeological glasses, mosaic vitreous tesserae (non crystalline or only partially crystalline materials) and ceramic, metals, their corrosion products, slags, stones, mortars and pigments (partially or almost completely crystalline materials). For this reason, the paper will present only a number of possible applications of X-ray diffraction to Cultural Heritage conservation studies. We have to reflect on the fact that this position may appear limiting, since many other materials, such as bone, ivory, gems, leather, 
parchment, organic binders and so on, are not discussed here. We have to consider that also in the case of these different materials, X-ray diffraction plays a very important role for their characterization.

Another important purpose of this work remains to encourage in-depth studies regarding the use of X-ray techniques in the study of historical, archaeological and artistic materials.

\section{Experimental Methodology}

Given the generally great historical, artistic and cultural importance of the materials under study, it was always pursued a nondestructive approach, based on the interaction between electromagnetic waves and the artworks in question. This has led to the achievement of a methodology based on the use of different complementary techniques forming a set of non destructive (or micro-destructive) techniques able to perform a complete characterization of the objects. For a better characterization a variety of examined areas were chosen depending on the different materials.

The following archaeometric techniques were applied:

\subsection{X-Ray Diffraction}

X-ray diffractograms were obtained operating directly on the objects of sufficient small dimensions or on the powders of the micro-sampling by means of a PW1729 Philips Diffractometer (Ni-filtered CuKa radiation) over a range of 2 theta $=6^{\circ}-90^{\circ}$ (step of $0.02^{\circ}-0.05^{\circ}$ and acquisition time of $2-5 \mathrm{~s}$ ). In several cases a Guinier camera was also used.

\subsection{Fourier Transform Infrared Analysis}

A Perkin-Elmer Spectrum One FTIR, equipped with the Universal ATR Sampling Accessory (ZnSe cell), was used to obtain $4 \mathrm{~cm}^{-1}$ resolution spectra in the $550-4000 \mathrm{~cm}^{-1}$ region, scanned 10 times. The ATR device allowed us to analyze the samples at room temperature and humidity, without any treatment of heating and $\mathrm{KBr}$ grinding. When necessary (hot analyses), samples were heated $15 \mathrm{~min}$ in a $750 \mathrm{~W}$ microwave oven immediately before performing the infrared analysis.

\subsection{Optical Microscopy and Macrophotography}

Optical observation and photographic documentation were achieved using a Dino-lite portable digital microscope and a Canon EOS 350D camera equipped with a Canon ZoomLens EF-S 18 - 55 mm.

\subsection{X-Ray Fluorescence Spectrometry}

Elemental analysis was performed using a Lithos 3000 portable system and an appropriate Lithos program by Assing to process the data. The apparatus consists of a Mo tube, a $\mathrm{Zr}$ filter and a semiconductor $\mathrm{Si}(\mathrm{Li})$ detector, cooled by Peltier effect. The operating parameters were: $25 \mathrm{kV}, 0.1 \mathrm{~mA}$, and 120 - 240 seconds of acquisition time. The elements with the highest intensity detected on the samples, such as $\mathrm{Pb}, \mathrm{Fe}$ or $\mathrm{Hg}$, have been used as internal standards.

\subsection{Reflectance Spectrophotometry}

Reflectance spectrophotometric and colour measurements have been performed using a Minolta CM-2600 portable spectrophotometer, provided with a Xenon lamp to pulsate the light on the sample surface and with an integrative sphere inside the apparatus. Visible light is reflected by the observation surface with an angle of $8^{\circ}$. It is captured by a silicon photodiode that measures the spectrum between 360 and $740 \mathrm{~nm}$ with an interval of $10 \mathrm{~nm}$. Colour coordinates are based on the CIEL*a*b* system using an illuminant D65 with an observer angle of $10^{\circ}$. In this system, $\mathrm{L}^{*}$ represents colour lightness, while $\mathrm{a}^{*}$ and $\mathrm{b}^{*}$ are the coordinates of chromaticity. Coordinate $+a^{*}$ and $-a^{*}$ indicate red and green values, while $+b^{*}$ and $-b^{*}$ indicate the yellow and blue values, respectively.

\subsection{UV Fluorescence}

This analysis was carried out mainly on paints using a ceiling light with four Sylvania black light-blue F18W/ BLB-T8 tubes. The digital camera used for recording images is the Canon EOS 350D without barrier filter. It is 
a non-destructive superficial analysis that identifies the presence of one or more film-forming substances, such as varnishes applied on the artwork (resins, oleoresins, proteins, etc.) and, generally, every previous intervention. This technique allows assessing the condition of the paint, enhancing the presence of restorations, biological attacks, even when they appear indistinguishable to the naked eye. Also, it can give some information on pigments or corrosion products that may have their own particular fluorescence.

\section{Cellulose-Based Materials}

\subsection{Paper}

As it is well known, the paper consists of two main components: cellulose and additives; cellulose obtained from linen rags, cotton rags and wood pulp, and additives, consisting of dyes, fillers and binders. Cellulose is only partially crystalline and the technique used for its characterization consists in determining the crystallinity value that decreases owing to the ageing. The causes of deterioration of library materials, chemical, physical or biological, are widely discussed [2]-[7].

The raw materials and the manufacture of the paper varied on the time: the oldest papers, which consisted entirely of cloth cellulose, maintain and preserve its chemical and physical characteristics over time, when stored in an appropriate environment. At the contrary, recent papers present, for a series of reasons, increasing problems for their conservation [7] [8]. The crystallinity and relative index of crystal dimensions were assumed as a qualitative evaluation of the mechanical properties of cellulose fibres and, consequently for the paper conservation properties. For this purpose the wide-angle X-ray scattering (WAXS) technique was used. X-ray crystallinity $(\mathrm{Xc})$ and the relative index of average crystal dimensions $\left(1 / \mathrm{A}_{002}\right)$ were calculated as follows: the Xc value is the ratio $\left(\mathrm{I}_{002}-\mathrm{I}_{\text {amorph }}\right) / \mathrm{I}_{002}$, where $\mathrm{I}_{002}$ is the peak height at $2 \theta=22.5^{\circ}$ and $\mathrm{I}_{\text {amorph }}$ is the background intensity at $2 \theta=20^{\circ}$, while $\mathrm{A}_{002}$ is the full width at half height of the $22.5^{\circ} 2 \theta$ peak. In Figure $1 \mathrm{X}$-ray pattern for Whattman pure cellulose paper is compared to that of amorphous cellulose.

Through this methodology it was possible to follow several alteration reactions of a standard paper and of real papers [7] [8].

\subsection{Wood}

In a similar way, XRD data were used in evaluating the crystallinity degree for cellulose inside different kinds of wood natural, artificially aged and waterlogged archaeological samples. The results have been useful to recognize the effect of time on the wood structure and properties, as well to evaluate the effect of the presence of metals inside the woods they self. Regarding to the metals, the alteration effect of copper is generally stronger than that of iron [9]-[12].

The colour measurements, carried on the various samples of wood in function of the ageing time, are in agreement with the wood degradation results. In other words, more increases the wood alteration more dark becomes its colour [10].

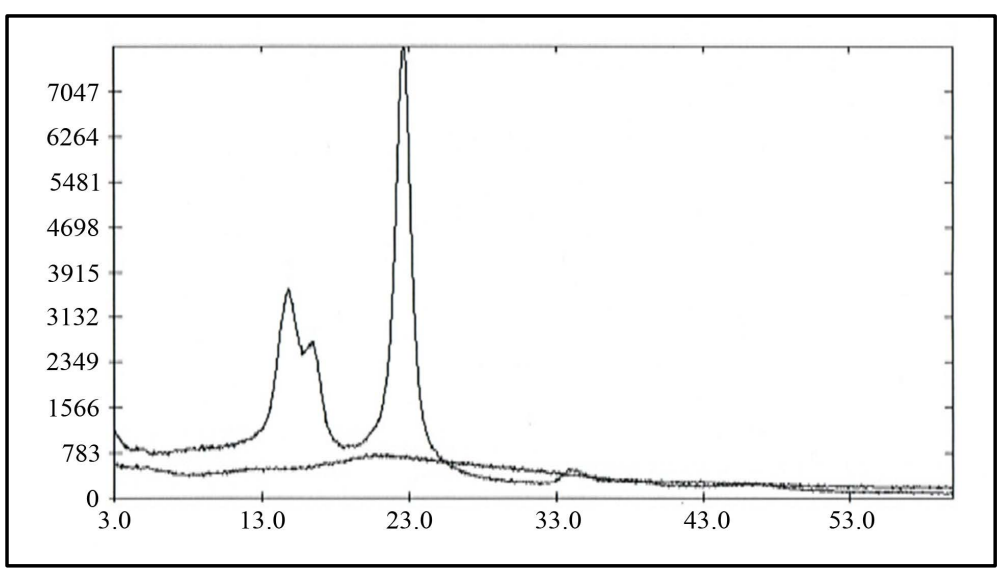

Figure 1. Wide angle X-ray diffraction pattern for Whatmann pure cellulose paper compared with amorphous cellulose. Intensity counts in arbitrary units versus $2 \theta_{\mathrm{Bragg}}$. 


\subsection{Papyrus}

During the studies performed on modern (manufactured at Museo del Papiro di Siracusa) and ancient papyrus sheets from Cairo Archaeological Museum) we used, besides the scanning electron microscopy (SEM) and optical microscope (OM), X-ray diffraction and thermal analyses. Interesting the results obtained, which highlighted the differences occurring in the manufacturing of Egyptian and Greek -Roman papyrus.

Another remarkable result was the microscope observation of the morphological features of the papyrus plant, still visible in ancient papyrus sheets, even if deformed as consequence of manufacturing and ageing. X-ray diffraction together with OM and SEM analyses highlighted different lignin contents in the various portions of the papyrus plant. In addition X-ray diffraction, thermal analyses and microscope observation were useful tools for the study of ancient papyri, contributing to identify the additives used in the manufacture of the papyrus sheets.

Calcium oxalate crystals and starch granules have been detected, showing that the ancient Egyptian sheets are richer in starch in comparison to the Greek-Roman papyrus. We observed that the Egyptian papyrus contains preferably starch, a material that naturally occurs in the plant as a reserve. In fact, found it in the residuals of the vascular bundle sheath, starch was detected. As a consequence, the Egyptian and Greek-Roman papyrus were also different in thermal behavior [13].

\section{Metals; Corrosion Products; Slags}

For these materials, mostly crystalline, the use of X-ray diffraction methods proved to be particularly useful. In the case of small metals, such as coins, they can be analysed putting them directly in the diffractometer itself. For the objects of major size we are obliged to draw some micro-samples in order to perform analyses. This fact forces us to consider this method, at least partially, destructive. In this case the Guinier method revealed to be particularly important in order to recognize small variations in lattice spacing due to solid solutions occurring in alloys [14]-[25], as well in distinguishing small structural differences that occur between similar corrosion products [25] [26].

In the studies concerning the ancient statuary and the archaeological metal remains, the alloy composition and the nature of corrosion products have been often evaluated [19]-[26] by means of X-ray powder diffraction, using a Guinier camera.

In Figure 2 an example of its preparation is shown, where Si powder was used as standard for correct the $\mathrm{X}$-ray diffraction lines of two different corrosion products. A data base for the main corrosion products of bronze was developed, particularly useful for a secure and rapid evaluation in the study of archaeological bronzes [27].

Figure 3 shows the comparison between the X-ray diffraction patterns of two common corrosion products of the bronze statues exposed to a marine environment, atacamite and paratacamite, with the same chemical formula, $\mathrm{Cu}_{2} \mathrm{Cl}(\mathrm{OH})_{3}$.

In Figure 4 a pre-roman coin signed ALBINTIMILIUM formed by almost pure lead is shown [26].

The X-ray diffraction performed directly by placing the coin within an automatic diffractometer allowed us to recognize the superficial mineralization of lead to form lead carbonate; all the peaks could be indexed on the basis of the orthorhombic structure of cerussite with $a=5.195 \AA, b=8.436 \AA, c=6.152 \AA$.

An example of corrosion products on a roman age bronze statue is shown in Figure 5, in correspondence of a

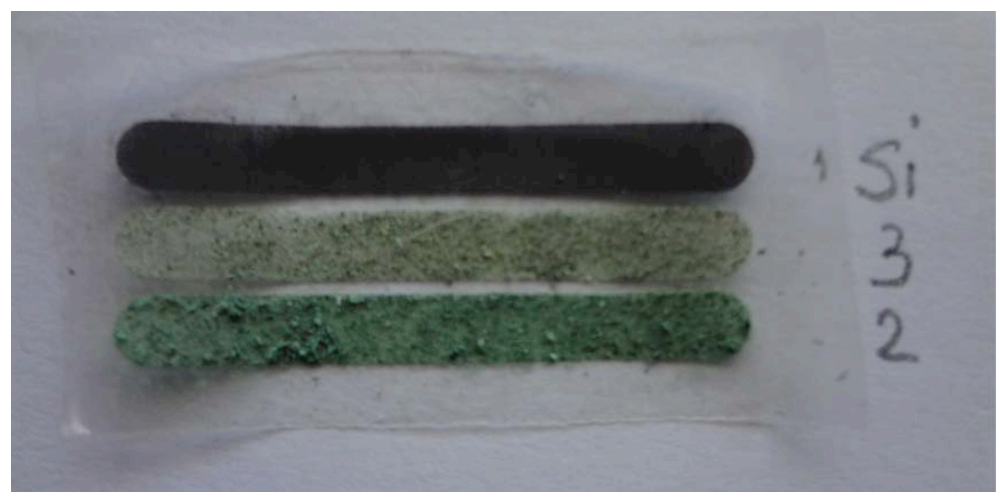

Figure 2. Powder samples for performing analysis by means of a Guinier camera. 

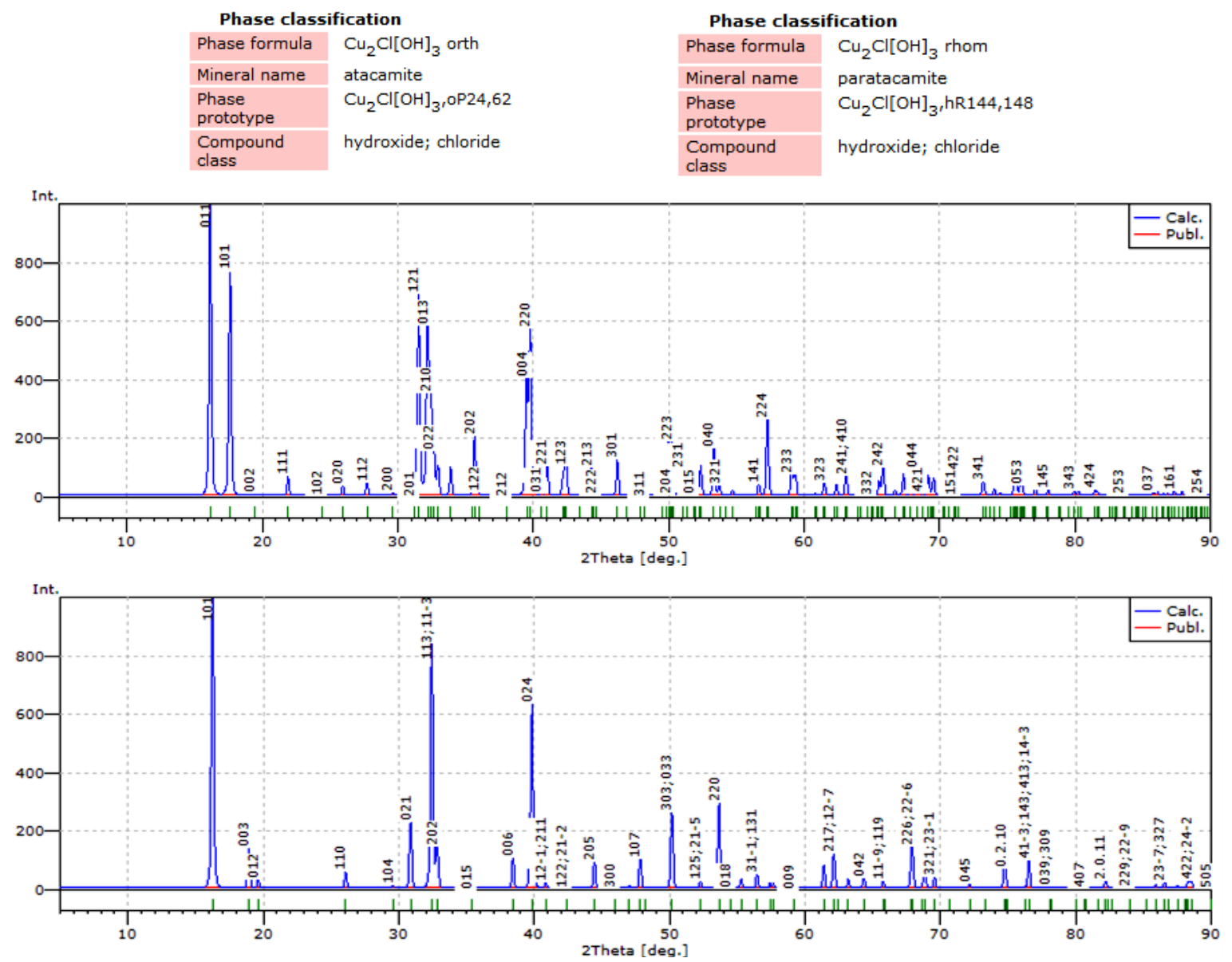

Figure 3. X-ray powder diffractograms for atacamite (above) and paratacamite (below), two common corrosion products of bronze (Source: P. Villars, K. Cenzual, Pearson's Crystal Data: Crystal Structure Database for Inorganic Compounds (on DVD), Release 2013/14, ASM International ${ }^{\circledR}$, Materials Park, Ohio, USA).

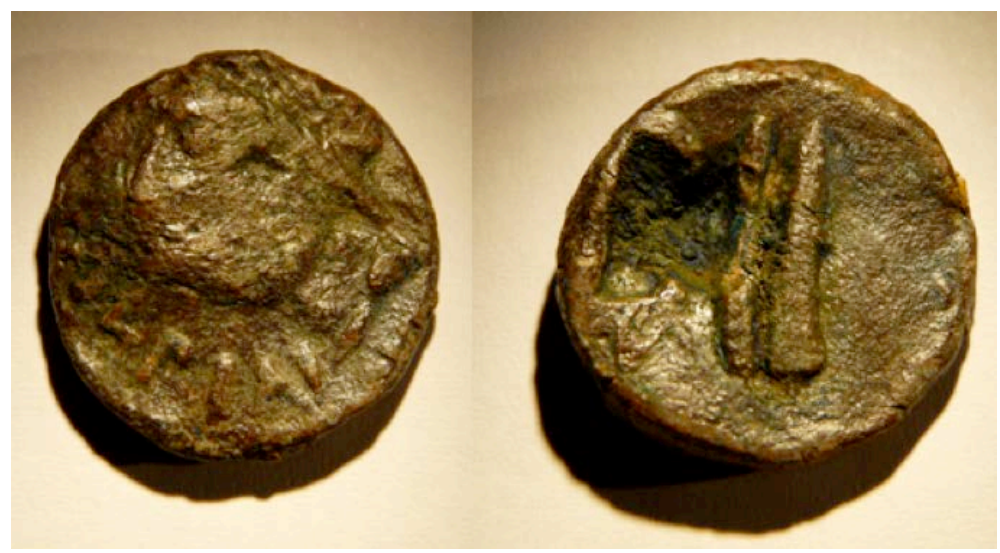

Figure 4. A pre-roman lead coin signed ALBINTIMILIUM.

junction point.

The study of slags, coming from different archaeological sites, was performed by using both X-ray diffraction methods and optical and scanning electron microscopy [28] [29].

The variation of lattice spacing for annealed bronzes of different composition, following the linear trend typical for solid solutions, known as Vegard's law, is shown in Figure 6. This experimental behaviour, as similar 


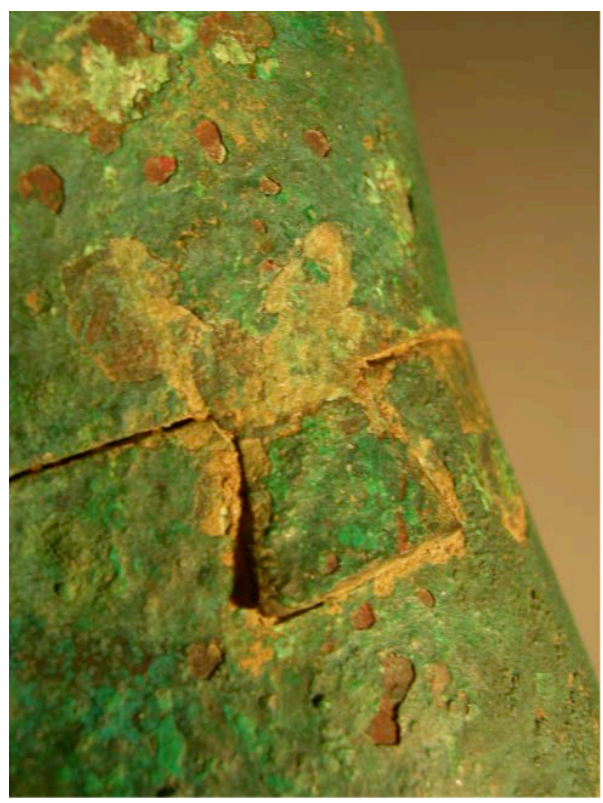

Figure 5. Corrosion products on a roman statue.

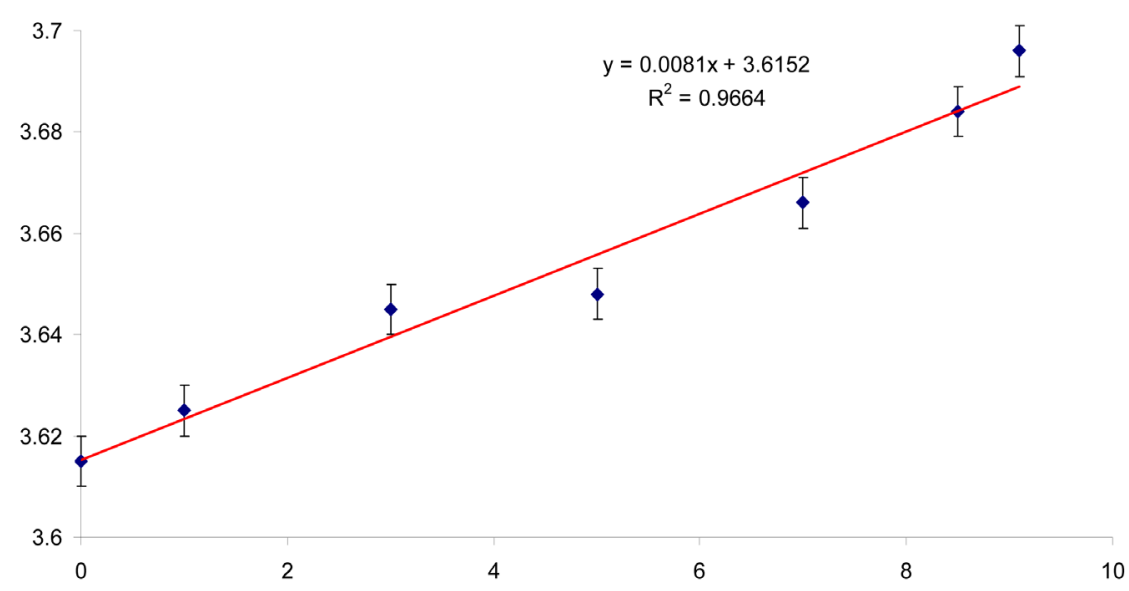

Figure 6. Vegard's law showing the linear dependence of lattice spacing on the composition: $\mathrm{y}$-axis reports the value of the lattice constant in $\AA$ versus the composition in atomic \% of tin in the annealed bronzes.

ones obtained for $\mathrm{Cu}-\mathrm{As}$ and $\mathrm{Cu}-\mathrm{Zn}$ solid solutions, are useful in evaluating the composition of a binary archaeological alloy.

In Figure 7 a microscope image of a slag section from copper smelting process [29] is reported.

\section{Stone; Mortars}

X-ray diffraction is an important tool in studying this kind of materials in recognizing their composition, the degradation or conservation state and, in some cases, their provenance [30]-[33].

\section{Glass; Mosaic Tesserae}

$\mathrm{A} \mathrm{PhD} \mathrm{research} \mathrm{has} \mathrm{been} \mathrm{performed} \mathrm{on} \mathrm{archaeological} \mathrm{glasses} \mathrm{of} \mathrm{bronze} \mathrm{age} \mathrm{and} \mathrm{iron} \mathrm{age} \mathrm{coming} \mathrm{from} \mathrm{archaeo-}$ logical excavations carried out in Liguria [34]. The main investigation was conducted using X-ray fluorescence, optical microscopy and scanning electron microscopy analyses; but in some cases X-ray diffraction was used to identify the crystalline components present in the glass as colorant or opacifying agents. 


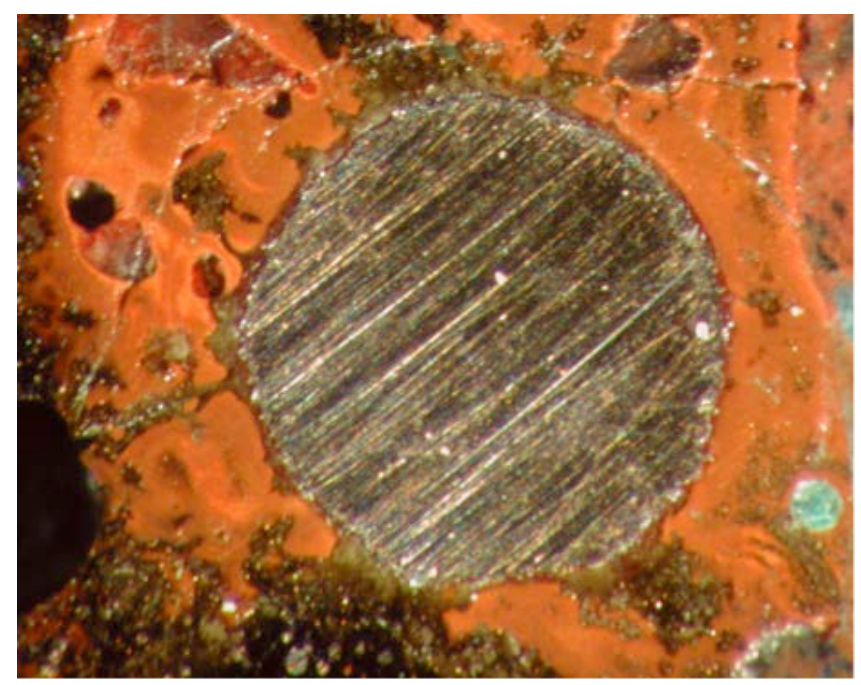

Figure 7. A Copper smelting slag, OM section $(\times 100$ in original).

A few studies have been conducted on mosaics, generally using a portable X-ray fluorescence apparatus [35]-[37]. When separate mosaic tesserae were available, the X-ray experiments were carried out directly on the tesserae, to avoid sampling.

\section{Pigments; Paints}

Obviously pigments, as crystalline materials are typically characterised by using X-ray diffraction methods [38]-[43]. In addition to characterizing and recognizing the pigments used in painting, X-ray powder diffraction and Gandolfi camera have been used, coupled with thermal analysis techniques, in order to determine their stability and recognize the degradation processes. For this purpose, works are in progress on a series of commercial pigments, like azurite, malachite, natural lapislazuli, Egyptian blue, or pigments prepared in our Laboratory, as copper acetate and copper neutral acetate. We plan to use synchrotron radiation to improve the recognition of the phase transition and the limits of thermal stability of each pigment, with the aim to define a scale of relative thermodynamic stability of pigments and their alteration products.

The purpose is to extend the study on the stability of the pigments to the durability of paints and works of art.

\section{Conclusion}

As already remarked, in studying cultural, archaeological, artistic materials, it is necessary to perform a set of complementary chemical physical investigations in order to have the most complete characterization of the objects. X-ray diffraction revealed to be a helpful tool in the characterization not only of crystalline phases, but also in the almost amorphous materials. The studies developed in over twenty years of activity in different sectors of Cultural Heritage conservation, provided very useful information to archaeologists, art historians, conservators and restorers.

\section{Acknowledgements}

I wish to thank my dear Colleagues Paolo Bensi, Paolo Calvini, Marilena Carnasciali, Vittorio Contardi, Giorgio Costa and Enrico Pedemonte, for their continuous encouragement.

Warm thanks go to all my collaborators, who, with their enthusiasm, work and time, allowed me to carry out my archaeometric research:

Nadia Campana, Francesca Carosi, Ivano Cascone, Davide Delfino, Michele Ferrari, Chiara M. Franceschi, Marco Gagnesi, Michela Giorgi, Patrycja Kita, Federico Locardi, Giorgio Luciano, Luisella Macciò, Marco Maggi, Angelita Mairani, Pietro Manfrinetti, Marco Marino, Pieter Matthaes, Ugo Meo, Mario Minguzzi, Dion Nole, Daniela Palazzi, Bruno Peripimeno, Paolo Piccardo, Elisabetta Princi, Claudio Repetto, Lucilla Rosa, Marta Salotti, Barbara Turri, Stefano Vassallo, Silvia Vicini. 


\section{References}

[1] Uda, M., Demortier, G. and Nakai, I. (2005) X-Rays for Archaeology. Springer, Amsterdam. http://dx.doi.org/10.1007/1-4020-3581-0

[2] Calvini, P., Franceschi, E. and Palazzi, D. (1997) Traditional and New Methodologies in the Study of Paper Degradation. Proceedings of 1st International Congress on Science and Technology for the Safeguard of Cultural Heritage in the Mediterranean Basin, Catania, Siracusa, 27 November-2 December 1995, 1245-1248.

[3] Franceschi, E., Palazzi, D. and Pedemonte, E. (2001) Thermoanalytical Contribution to the Study on Paper Degradation: Characterisation of Oxidised Paper. Journal of Thermal Analysis and Calorimetry, 66, 349-358. http://dx.doi.org/10.1023/A:1012428824378

[4] Franceschi, E., Luciano, G., Carosi, F., Cornara, L. and Montanari, C. (2004) Thermal and Microscope Analysis as a Tool in the Characterization of Ancient Papyri. Thermochimica Acta, 418, 39-45. http://dx.doi.org/10.1016/j.tca.2003.11.051

[5] Vicini, S., Princi, E., Luciano, G., Franceschi, E., Pedemonte, E., Oldak, D., Kaczmarek, H. and Sionkowska, A. (2004) Thermal Analysis and Characterisation of Cellulose Oxidised with Sodium Methaperiodate. Thermochimica Acta, 418, 123-130. http://dx.doi.org/10.1016/j.tca.2003.11.049

[6] Princi, E., Vicini, S., Pedemonte, E., Mulas, A., Franceschi, E., Luciano, G. and Trefiletti, V. (2005) Thermal Analysis and Characterisation of Cellulose Grafted with Acrylic Monomers. Thermochimica Acta, 425, 173-179. http://dx.doi.org/10.1016/j.tca.2004.07.001

[7] Calvini, P., Gorassini, A., Luciano, G. and Franceschi, E. (2006) FTIR and WAXS Analysis of Periodate Oxycellulose: Evidence for a Cluster Mechanism of Oxidation. Vibrational Spectroscopy, 40, 177-183. http://dx.doi.org/10.1016/j.vibspec.2005.08.004

[8] Franceschi, E. (2011) Thermoanalytical Methods: A Valuable tool for the Study of Cellulose Based Materials of Art and Archaeology. Journal of Thermal Analysis and Calorimetry, 104, 527-539. http://dx.doi.org/10.1007/s10973-011-1343-x

[9] Franceschi, E., Cascone, I. and Nole, D. (2008) Thermal, XRD and Spectrophotometric Study on Artificially Degraded Woods. Journal of Thermal Analysis and Calorimetry, 91, 119-123. http://dx.doi.org/10.1007/s10973-007-8372-5

[10] Franceschi, E., Cascone, I. and Nole, D. (2008) Study of Artificially Degraded Woods Simulating Natural Ageing of Archaeological Findings. Journal of Thermal Analysis and Calorimetry, 92, 319-322. http://dx.doi.org/10.1007/s10973-007-8722-3

[11] Franceschi, E., Cascone, I., Nole, D. and Calvini, P. (2008) Caratterizzazione chimico fisica di legni bagnati e confronto con legni archeologici GRADUS. Rivista di Archeologia dell'acqua, 3, 79-90.

[12] Vecchio, S., Luciano, G. and Franceschi, E. (2006) Explorative Kinetic Study on the Thermal Degradation of Five Wood Species for the Application in the Archaeological Field. Annali di Chimica, 96, 715-725. http://dx.doi.org/10.1002/adic.200690074

[13] Franceschi, E., Luciano, G., Carosi, F., Cornara, L. and Montanari, C. (2004) Thermal and Microscope Analysis as a Tool in the Characterization of Ancient Papyri. Thermochimica Acta, 418, 39-45. http://dx.doi.org/10.1016/j.tca.2003.11.051

[14] Stagno, E., Ienco, M.G., Pinasco, M.R., Franceschi, E., Campana, N. and Maggi, R. (1992) Studio di manufatti in bronzo del VII sec. a. C. provenienti dalla Necropoli di Chiavari. La Metallurgia Italiana, 84, 795-804.

[15] Franceschi, E. and Campana, N. (1992) Analisi di manufatti metallici preistorici e protostorici dal Castellaro di Uscio. In: Archeometallurgia: Ricerche e prospettive, Cooperativa Libraria Universitaria Editrice, Bologna, 527-534.

[16] Franceschi, E., Manfrinetti, P., Minguzzi, M. and Palazzi, D. (1994) Microdestructive Sampling and Analyzing Methods in the Characterization of Ancient Metallic Artifacts. Proceedings of 4th International Conference on Non-Destructive Testing of Works of Art, Berlin, 3-8 October 1994, 713-722.

[17] Ienco, M.G., Pinasco, M.R., Stagno, E., Campana, N., Maggi, R. and Franceschi, E. (1995) Some Aspects of Metallurgical Technologies in Prehistoric and Protohistoric Liguria. Praktische Metallographie, 4, 166-181.

[18] Franceschi, E., Macciò, L. and Palazzi, D. (1998) A Physical Chemical Contribution to the Knowledge of Ancient Statuary: Investigations on Some Metallic Objects from the Capitoline Museums, Rome. Praktische Metallographie, 35, 681-691.

[19] Franceschi, E. (2000) Syntèse de dix ans de recherche sur la première métallurgie en Ligurie (1988-1998). Proceedings of 2nd International Congress on Science and Technology for the Safeguard of Cultural Heritage in the Mediterranean Basin, Paris, 5-9 July 1999, Vol. 1, 521-525.

[20] Franceschi, E., Palazzi, D. and Rosa, L. (2001) Indagini chimico fisiche su reperti metallici ritrovati in una tomba campaniforme in località Castellari, presso Loano (Savona, Italia). Bell Beakers Today, Riva del Garda, 11-16 May 1998, Trento, 629-631. 
[21] Pifferetti, A.A., Franceschi, E. and Marino, M. (2001) Estudio arqueometalurgico de una diadema del alto Anchayuyo. Mendoza, Jornadas SAM, CONAMET_AAS 2001, Septiembre de 2001, 779-786.

[22] Franceschi, E., Giorgi, M., Luciano, G. and Palazzi, D. (2004) Archaeometallurgical Characterisation of Two Small Copper-Based Statues from the Cividale Museum (Friuli, Italy). Journal of Cultural Heritage, 5, 205-211. http://dx.doi.org/10.1016/j.culher.2003.07.004

[23] Franceschi, E., Cascone, I. and Nole, D. (2007) Non Destructive Characterisation of Several Copper-Based Finds from Different Archaeological Sites of Liguria (Italy). Archaeometallurgy 2007, Grado, Aquileia.

[24] Franceschi, E. (2008) Indagini archeometriche su due reperti metallici provenienti dal lago di Mezzano. In: Petitti, P. and Rossi, F., Eds., AES Metalli Preistorici dalla Tuscia, Catalogo della Mostra, Museo della Preistoria della Tuscia e della Rocca Farnese, Collana di Studi, Testi e Cataloghi, 2, Valentano, Rocca Farnese, 12 September-31 October 2008, $17-20$.

[25] Franceschi, E., Macciò, L., Palazzi, D. and Rosa, L. (1998) The Corrosion of Metallic Artifacts within Different Environments. Archaeological Objects and Laboratory Simulations. In: METAL 98, James \& James (Science Publishers), London, 92-93.

[26] Franceschi, E. and Palazzi, D. (2000) The Contribution of Micro-Destructive Investigations on Corrosion Layers to the Study of Provenance of Archaeological Bronze Artefacts. Proceedings of 2nd International Congress on Science and Technology for the Safeguard of Cultural Heritage in the Mediterranean Basin, Paris, 5-9 July 1999, Vol. 1, 413-416.

[27] Franceschi, E. and Nole D. Unpublished Results.

[28] Franceschi, E. (1998) Nuovi scavi nel complesso di S. Maria in Passione: Indagini archeometriche. Rivista di Studi Liguri, LXIII-LXIV (1997-1998), 309-313.

[29] Franceschi, E. and Luciano, G. (2003) Indagini archeometriche su alcune scorie provenienti dagli scavi di Nora. In: Giannattasio, B.M., Ed., NORA area c scavi 1996-1999, Brigati ed., Genova, 293-299.

[30] Contardi, V., Franceschi, E., Palazzi, D. and Pedemonte, E. (1994) Studies on Environmental Deterioration in slate Manufactured Articles of the Old Historical Centre of Genoa Using X-Ray Diffraction, Scanning Electron Microscopy, Calcimetry and Porosimetry. Some Investigations on Polymeric Materials Shielding. Science and Technology for Cultural Heritage, 3, 149-153.

[31] Contardi, V., Franceschi, E. and Palazzi, D. (1997) The Damaging of Pietra di Finale Consequent to the Action of Polluted Rains: Preliminary Investigations. Proceedings of 1st International Congress on Science and Technology for the Safeguard of Cultural Heritage in the Mediterranean Basin, Catania, Siracusa, 27 November-2 December 1995, 1091-1093.

[32] Contardi, V., Franceschi, E., Zanicchi, G., Palazzi, D., Bosio, S., Cortesogno, L. and Gaggero, L. (2000) On the Conservation of Architectural Artistic Handwork of the Pietra di Finale. Journal of Cultural Heritage, 1, 1-8.

[33] Bakolas, A., Biscontin, G., Contardi, V., Franceschi, E., Moropoulou, A., Palazzi, D. and Zendri, E. (1995) Thermoanalytical Research on Traditional Mortars in Venice. Thermochimica Acta, 269/270, 817-828

[34] Nole, D. (2012) Metodi chimico-fisici per i beni culturali: Studio archeometrico su materiali vitrei della liguria antica, Ph.D. Dissertation, University of Genoa, Genoa.

[35] Vassallo, S., Franceschi, E. and Nole, D. (2009) Indagini sul Sacrario dei Caduti della Prima guerra mondiale di Staglieno. In: Rossini, G. and Masi, C., Eds., Da Baroni a Piacentini, Immagine e memoria della Grande Guerra a Genova e in Liguria, SKIRA Editore, Milano, 186-190.

[36] Nole, D., Franceschi, E., Masi, C. and Vassallo, S. (2010) Indagini archeometriche non distruttive sui mosaici del sacrario dei caduti di Staglieno a Genova. In: Vandini, M., Ed., Riflessioni e Trasparenze: Diagnosi e Conservazione di Opere e Manufatti Vetrosi, Atti del V Congresso Nazionale dell’AIAr, Ravenna 24-26 febbraio 2009, Pàtron Editore, Bologna, 193-205.

[37] Franceschi, E., Nole, D. and Vassallo, S. (2010) Il mosaico del Battistero di Albenga. Indagini in fluorescenza X (XRF) e altre tecniche non invasivein Conservazione e restauro del mosaico antico e contemporaneo, Atti del Primo Convegno Internazionale, Ravenna 22-24 ottobre 2009, Bologna, 483-496.

[38] Mairani, A., Matthaes, P., Pedemonte, E., Franceschi, E., Bensi, P. and Terminiello, G. (1997) Bernardo Strozzi: An Example of Analytical Methodic. Proceedings of 1st International Congress on Science and Technology for the Safeguard of Cultural Heritage in the Mediterranean Basin, Catania, Siracusa, 27 November-2 December 1995, 575-577.

[39] Pedemonte, E., Franceschi, E., Lanata, M., Bensi, P. and Vicini, S. (2000) Pigments Analysis: Application of a Data Bank to the Investigation of an Ancient Sarcophagus. Proceedings of 2nd International Congress on Science and Technology for the Safeguard of Cultural Heritage in the Mediterranean Basin, Paris, 5-9 July 1999, Vol. 1, 595-597.

[40] Franceschi, E. and Cascone, I. (2008) I pigmenti pittorici: Una risposta della chimica. Dalla Terra nera alla Terra di Ponente, la collezione egizia del Museo di Archeologia Ligure, Collana Segni del Tempo, Il Portolano Editoria \& Comunicazione, Genova, 58-63. 
[41] Vassallo, S., Parodi, P., Franceschi, E., Cascone, I. and Nole, D. (2008) I dipinti murali di Luca Cambiaso nella villa Imperiale di Terralba: La conoscenza delle tecniche attraverso le indagini di laboratorio. In: Magnani, L. and Rossini, G., Eds., La “maniera” di Luca Cambiaso, San Giorgio Editrice, Genova, 221-227

[42] Cascone, I., Franceschi, E. and Nole, D. (2010) Analisi chimico-fisiche per la conoscenza della pittura di Valerio Castello. Il Ratto di Proserpina del Museo di Palazzo Reale. In: Leoncini, L. and Sanguineti, D., Eds., Valerio Castello Percorsi di approfondimento, Alessandria, Tipografia Viscardi, 293-303.

[43] Franceschi, C.M., Costa, G. and Franceschi, E. (2011) Aging of the Paint Palette of Valerio Castello (1624-1659) in Different Paintings of the Same Age (1650-1655). Journal of Thermal Analysis and Calorimetry, 103, 69-73. http://dx.doi.org/10.1007/s10973-010-1089-x 